\title{
Front Matter: Volume 7463
}

, "Front Matter: Volume 7463," Proc. SPIE 7463, Atmospheric Optics: Models, Measurements, and Target-in-the-Loop Propagation III, 746301 (10

September 2009); doi: 10.1117/12.844759

SPIE Event: SPIE Optical Engineering + Applications, 2009, San Diego, California, United States 


\section{PROCEEDINGS OF SPIE}

\section{Atmospheric Optics: Models, Measurements, and Target-in- the-Loop Propagation III}

Stephen M. Hammel

Alexander M. J. van Eijk

Mikhail A. Vorontsov

Editors

3-4 August 2009

San Diego, California, United States

Sponsored and Published by

SPIE 
The papers included in this volume were part of the technical conference cited on the cover and title page. Papers were selected and subject to review by the editors and conference program committee. Some conference presentations may not be available for publication. The papers published in these proceedings reflect the work and thoughts of the authors and are published herein as submitted. The publisher is not responsible for the validity of the information or for any outcomes resulting from reliance thereon.

Please use the following format to cite material from this book:

Author(s), "Title of Paper," in Atmospheric Optics: Models, Measurements, and Target-in-the-Loop Propagation III, edited by Stephen M. Hammel, Alexander M. J. van Eijk, Mikhail A. Vorontsov, Proceedings of SPIE Vol. 7463 (SPIE, Bellingham, WA, 2009) Article CID Number.

ISSN 0277-786X

ISBN 9780819477538

Published by

SPIE

P.O. Box 10, Bellingham, Washington 98227-0010 USA

Telephone +1 3606763290 (Pacific Time) · Fax +1 3606471445

SPIE.org

Copyright (C) 2009, Society of Photo-Optical Instrumentation Engineers

Copying of material in this book for internal or personal use, or for the internal or personal use of specific clients, beyond the fair use provisions granted by the U.S. Copyright Law is authorized by SPIE subject to payment of copying fees. The Transactional Reporting Service base fee for this volume is $\$ 18.00$ per article (or portion thereof), which should be paid directly to the Copyright Clearance Center (CCC), 222 Rosewood Drive, Danvers, MA 01923. Payment may also be made electronically through CCC Online at copyright.com. Other copying for republication, resale, advertising or promotion, or any form of systematic or multiple reproduction of any material in this book is prohibited except with permission in writing from the publisher. The CCC fee code is 0277-786X/09/ $\$ 18.00$.

Printed in the United States of America.

Publication of record for individual papers is online in the SPIE Digital Library.

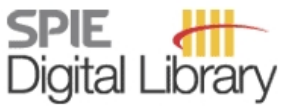

SPIEDigitalLibrary.org

Paper Numbering: Proceedings of SPIE follow an e-First publication model, with papers published first online and then in print and on CD-ROM. Papers are published as they are submitted and meet publication criteria. A unique, consistent, permanent citation identifier (CID) number is assigned to each article at the time of the first publication. Utilization of CIDs allows articles to be fully citable as soon they are published online, and connects the same identifier to all online, print, and electronic versions of the publication. SPIE uses a six-digit CID article numbering system in which:

- The first four digits correspond to the SPIE volume number.

- The last two digits indicate publication order within the volume using a Base 36 numbering system employing both numerals and letters. These two-number sets start with 00, 01, 02, 03, 04, $05,06,07,08,09,0 A, 0 B \ldots 0 Z$, followed by 10-1Z, 20-2Z, etc.

The CID number appears on each page of the manuscript. The complete citation is used on the first page, and an abbreviated version on subsequent pages. Numbers in the index correspond to the last two digits of the six-digit CID number. 


\section{Contents}

$\checkmark$ Conference Committee

SESSION 1 OPTICAL TURBULENCE CHARACTERIZATION AND LINK MODELING: JOINT SESSION WITH CONFERENCE 7464

746302 Attenuation measurement on dual-wavelength optical free-space link [7463-01]

O. Fiser, J. Svoboda, Z. Chladova, P. Pesice, J. Fisak, Institute of Atmospheric Physics (Czech Republic); O. Wilfert, Z. Kolka, Brno Univ. of Technology (Czech Republic); V. Brazda, J. Jaros, Pardubice Univ. (Czech Republic)

746303 Experiment to characterize optical turbulence along a $2.33 \mathrm{~km}$ free-space laser path via differential image motion measurements [7463-02]

A. Tunick, U.S. Army Research Lab. (United States)

\section{SESSION 2 OPTICAL TURBULENCE}

746304 Weak and strong beam scintillations for the ground-to-space propagation [7463-03] M. Charnotskii, Zel Technologies, LLC (United States) and NOAA (United States)

746305 Laser guide star scintillometer (LAGUSS) for profiling atmospheric furbulence [7463-04] A. Khizhnyak, V. Markov, MetroLaser, Inc. (United States)

746306 A new technique for probing length scales in clear air [7463-05]

C. C. Davis, J. D. Harris, R. W. Gammon, Univ. of Maryland, College Park (United States)

746307 Imaging and communications through non-Kolmogorov turbulence [7463-06]

N. S. Kopeika, A. Zilberman, E. Golbraikh, Ben-Gurion Univ. of the Negev (Israel)

746308 The balloon ring: a high-performance low-cost instrumentation plafform for measuring atmospheric turbulence profiles [7463-07]

D. T. Kyrazis, R-Cubed, Inc. (United States); F. D. Eaton, Air Force Research Lab. (United States); D. G. Black, W. T. Black, Ridgeline LLC (United States); A. Black, R-Cubed, Inc. (United States)

746309 Preliminary VHF radar and high-data-rate optical turbulence profile observations using a balloon-ring plafform [7463-08]

F. D. Eaton, Air Force Research Lab. (United States); G. D. Nastrom, St. Cloud State Univ. (United States); D. T. Kyrazis, R-Cubed, Inc. (United States); D. G. Black, W. T. Black, Ridgeline, LLC (United States); R. A. Black, R-Cubed, Inc. (United States)

7463 OA Using experimental data from a balloon experiment to assess optical performance [7463-09]

T. T. Clark, C. A. Clarke, Tau Technologies (United States) 
$7463 \mathrm{OB} \quad$ Generating an accurate vertical aerosol profile [7463-10]

S. Hammel, B. Bachmann, Space and Naval Warfare Systems Ctr. Pacific (United States)

\section{SESSION 3 BEAM PROPAGATION AND IMAGE QUALITY}

7463 OC Automated video enhancement from a stream of atmospherically-distorted images: the lucky-region fusion approach [7463-11]

M. Aubailly, Univ. of Maryland, College Park (United States); M. A. Vorontsov, Univ. of Maryland, College Park (United States) and Army Research Lab. (United States);

G. W. Carhart, Army Research Lab. (United States); M. T. Valley, Sandia National Labs. (United States)

7463 OD Analysis and deconstruction of mirages to assess environmental features [7463-12] M. A. C. Degache, A. M. J. van Eijk, TNO Defence, Security and Safety (Netherlands);

S. M. Hammel, D. Tsintikidis, Space and Naval Warfare Systems Ctr. Pacific (United States)

$7463 \mathrm{OE} \quad$ Influence of aerosols on off-axis laser detection capabilities [7463-13]

J. Kusmierczyk-Michulec, R. H. M. A. Schleijpen, TNO Defence, Security and Safety (Netherlands)

7463 OF Wavelet-based phase determination in optical turbulence [7463-14]

K. J. Jones, WBAO (United States)

\section{SESSION 4 ATMOSPHERIC EFFECTS}

7463 OG The Ångström coefficient as an indicator of non-marine particles in ANAM (Advanced Navy Aerosol Model) [7463-15]

J. Kusmierczyk-Michulec, A. M. J. van Eijk, TNO Defence, Security and Safety (Netherlands)

$7463 \mathrm{OH} \quad$ Laser tracker TSPI uncertainty quantification via centrifuge trajectory [7463-16]

E. Romero, T. Paez, T. Brown, T. Miller, Sandia National Labs. (United States)

Author Index 


\title{
Conference Committee
}

\author{
Conference Chairs
}

Stephen M. Hammel, Space and Naval Warfare Systems Center, San Diego (United States)

Alexander M. J. van Eijk, TNO Defense, Security and Safety (Netherlands)

Mikhail A. Vorontsov, Army Research Laboratory (United States)

Program Track Chairs

Stephen M. Hammel, Space and Naval Warfare Systems Center, San Diego (United States)

Alexander M. J. van Eijk, TNO Defense, Security and Safety (Netherlands)

Program Committee

Matthew M. Bold, Lockheed Martin Space Systems Company (United States)

Frank D. Eaton, Air Force Research Laboratory (United States)

Charles Higgs, MIT Lincoln Laboratory (United States)

Vladimir B. Markov, MetroLaser, Inc. (United States)

Vincent Michau, ONERA (France)

Jennifer C. Ricklin, Defense Advanced Research Projects Agency (United States)

Jim F. Riker, Air Force Research Laboratory (United States)

Michael C. Roggemann, Michigan Technological University (United States)

Don D. Seeley, High Energy Laser Joint Technology Office (United States)

Alexander M. Sergeev, Institute of Applied Physics (Russian Federation) Michael T. Valley, Sandia National Laboratory (United States)

Thomas Weyrauch, University of Maryland, College Park (United States)

Session Chairs

1 Optical Turbulence Characterization and Link Modeling: Joint Session with Conference 7464

Alexander M. J. van Eijk, TNO Defence, Security and Safety (Netherlands)

Christopher C. Davis, University of Maryland, College Park

(United States) 
2 Optical Turbulence

Stephen M. Hammel, Space and Naval Warfare Systems Center, San Diego (United States)

3 Beam Propagation and Image Quality

Jolanta Kusmierczyk-Michulec, TNO Defence, Security and Safety

(Netherlands)

$4 \quad$ Atmospheric Effects

Alexander M. J. van Eijk, TNO Defence, Security and Safety

(Netherlands) 